\title{
Why Academics Should Study the Supply Chains of Specific Corporations
}

Benjamin Goldstein and Joshua Newell

University of Michigan - School for Environment and Sustainability, Michigan, USA.

Summary

Although fields such as industrial ecology have advanced our understanding of how cleaner technologies, recycling, and lifestyle changes can reduce the impacts of production and consumption on people and planet, environmental deterioration and social injustices stubbornly persist. New strategies are needed to achieve change in an era of increasing urgency. This paper proposes that academics study the supply chains of specific corporations and link them to environmental and social impacts in geographically specific areas. Nongovernmental organizations (NGOs) have used this approach successfully, issuing reports about corporate activity related to deforestation, sweatshops, and other issues of social concern. But academics, by and large, have studied generic products, industries, and sectors. To verify this, after reviewing $\sim 11,000$ studies on supply chains, we identified just fifty-seven papers that focused on specific corporations. These were primarily by NGOs and social scientists, with no studies by industrial ecologists meeting our review criteria. To uncover corporate supply chains, researchers used two distinct methodological approaches: in-situ (interviews, surveys, and surveillance) and ex-situ (trade data, document analysis, and maps). In this paper, we explain why and how academics should study the supply chains of specific corporations. This is done by combining approaches from industrial ecology, with those from geography, sociology, and other social sciences to develop a political-industrial ecology of supply chains. This both physically links of actual product flows with their environmental impacts, and explores how they affectjustice, equity, and welfare. The work we proposed offers clear collaborative linkages with NGOs, corporate actors, and the media.

Keywords: Sustainable business, environmental justice, global value chain, nongovernmental organization (NGO), political-industrial ecology, political ecology

Conflict of interest statement: The authors have no conflict to declare.

Address Correspondence to:

Benjamin Goldstein

University of Michigan - School for Environment and Sustainability, 440 Church St., Ann Arbor, Michigan 48109, USA

benigo@umich.edu

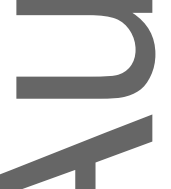

\section{Introduction (Heading level 1)}

We live in an age of corporate giants. Sixty-nine of the world's largest hundred economic entities companies, state agencies, municipalities - are in fact corporations. The revenue of Walmart Corp.

This is the author manuscript accepted for publication and has undergone full peer review but has not been through the copyediting, typesetting, pagination and proofreading process, which may lead to differences between this version and the Version of Record. Please cite this article as doi:

10.1111/jiec.12932. 
ranks $10^{\text {th }}$ globally, just slightly less than that of the Canadian government (Global Justice Now 2016). Walmart's revenue is larger than the agriculture, forestry and fishing industries of North America and the European Union combined'. A mere 100 companies account for $25 \%$ of global trade (Bartley 2018). Coca-Cola is the world's largest of consumer of sugarcane and aluminum, the second biggest consumer of glass, and the fourth largest consumer of coffee (Houpt 2011). Just 100 corporations are linked to almost $3 / 4$ of global greenhouse gas (GHG) emissions (Griffin 2017). Collectively, the 20 largest meat and dairy companies generate more GHGs than Germany (GRAIN and IATP 2018).

Copporate activities both immense in scale and global in geographic scope. Processes of globalization shuffle material, energy, information, money, and people across borders, oceans, and industries at increasing volumes and rates. Corporations produce, manage, tap into and lobby for the free movement of these flows. As a result, supply chains cross oceans, borders and industries and along the way they distribute environmental degradation and social upheaval unevenly (Dicken 2011).

For these reasons, changing corporate behavior must be part of any sustainable transition. Nongovernmental organizations (NGOs) have known this since the 1990s when they began investigating the supply chains of specific corporations. NGOs will often select a sector that faces social and environmental challenges, targeting brands in that sector (Gereffi et al. 2001; Bloomfield 2014). This has included Nike and Zara clothes and the use of child labor to produce their products (Schanberg 1996; Center for Research on Multinational Corporations 2016) and how oil palm for the likes of Cargill, Musim Mas, and Wilmar has led to illegal logging in the rainforests of Indonesia (WWF 2016a).

NGOs target well-known brands to gain leverage over corporations (Bloomfield 2014; Chrun et al. 2016). This strategy is effective since brands-carefully cultivated over time and valued in the hundreds of billions of dollars - are valuable corporate assets (Interbrand 2018). NGOs strategically identify sensitive corporate actors and their brands in problematic sectors (Bloomfield 2017, 2014). For instance, NGOS linked Nike, a brand associated with notions of freedom and empowerment, to child labor and sweatshops (Bartley 2018). NGOs will organize protests and boycotts and sway public opinion through the media (Dauvergne 2017; Bloomfield 2014; Spar and La Mure 2003). NGOs will also compare sustainability laggards against sustainability leaders (Bloomfield 2014). Using these 'media politics', NGOs maximize limited budgets and nudge corporations and entire sectors towards sustainability (Klooster 2006, 2005). As these campaigns can devalue brands, reduce sales and result in stock market penalties (O'Rourke 2014; Spar and La Mure 2003), corporations will often commit to 'cleaning up' their supply chains. These campaigns can also influence voting shareholders, such as ethical investment funds, with influence over corporate decision making (Bartley 2018). By linking palm-oil to deforestation in Southeast Asia, for instance, or Greenpeace pushed McDonald's, Unilever and Proctor \& Gamble to introduce "zero deforestation" pledges (Dauvergne 2017). Proactive companies will collaborate with stakeholders to develop sustainability standards. Recalcitrant companies may risk legal action by NGOs and regulatory agencies (Gibson and Warren 2016; Spar and La Mure 2003). 
Given the scale of corporate operations, targeting a few key actors in key sectors can have a profound impact. As such, corporate supply chains represent a potent and much needed research area. For O’Rourke (2005), academics (including industrial ecologists) should not only study corporate supply chains but also collaborate with NGOs. Academics, after all, enjoy much greater confidence and trust among the public than do those in business, government or media (Edelman 2017). This puts sustainability scholars in an enviable position with respect to research on the environmental and social impacts of the supply chains of specific corporate actors.

So how often have academics taken up O'Rourke's call to study supply chains in this way? What segments of academia are doing this research and what data and methods are they using? We answer these questions through an inventory of $\sim 11,000$ publications on supply chains from the academic and 'grey' literature. Our findings indicate just 57 papers on corporate specific supply chains, with little activity by industrial ecologists. To advance research in this area, we briefly present a methodologically to link corporate supply actors across space and time by coming ex-situ and insitu data gathering techniques with methods in industrial ecology. This builds on work by NGOs and social scientists to effectively form a political-industrial ecology of corporate supply chains. To bring about concrete change, we note how academics can publish results, build websites and partner with NGOs to communicate findings to the broader public in order to encourage more sustainable behavior by corporations and industry sectors.

\section{Identifying the Relevant Literature (Heading level 1)}

We used Scopus to search for relevant literature in the social sciences, engineering, and natural sciences-over a fifty-year period (1966 and 2017) (Table S1 in the supporting information S1 available on the Journal's website). Queries covered the various academic terms for supply chains, such as 'global value chains', 'global commodity chains', 'global production networks', and 'supply chain management'. We began with broad search terms (e.g. "supply chain management" AND "case study"), refining them iteratively based on the results of the query. Scanning literature on supply chain management, for instance, revealed "value stream analysis" and "value stream mapping" as necessary search strings.

Studies had to fulfill four criteria:

1) Studies needed to name specific companies or brands.

2) Studies had to cover multiple companies coordinating different tasks and operating together to form a supply chain (e.g. Company A manufacturing batteries and Company B assembling cellphones).

3) Studies had to reveal previously unknown connections between different companies. For instance, we would not include a study reiterating company links from a corporate report (e.g. Company A reports selling to Company B), but we would include a study capturing additional links (e.g. Company B reports selling to Company C, who is then indirectly linked to Company A).

4) Studies could not be based on collaborations with companies (e.g. supplier audit done by researcher). 
These criteria excluded work that might seem relevant at first glance, such as LCAs that map a company's supply chain but do not identify their suppliers (Smith et al. 2017). For similar reasons, we omitted LCAs only covering a company's direct operations (Meinrenken et al. 2014). Moreover, corporations often conceal problematic suppliers (Lebaron and Lister 2015) or are unaware of whom their suppliers source from (O'Rourke 2014). Thus, we excluded supplier audits and work using published information on suppliers, as these are rare instances when corporations know and are willing to share these data. In sum, we included studies that linked specific companies to their specific suppliers without the benefit of pre-existing mapping of the supply chain. Illuminating how researchers can overcome this challenge is a primary goal of this review.

We applied these criteria for the Scopus search in the keywords, highlights, title, and abstract. Despite potential omissions, we found enough candidate texts using this method to feel confident that the findings are representative of the academic literature on corporate specific supply chains. Having identified promising studies, we then skimmed the text, followed by a full reading of the paper once we were certain that it met our criteria.

Toidentify the 'grey literature' we conducted unstructured Google queries and searched NGO websites (as of December 2017), including those of: Amnesty International, Greenpeace, Environmental Investigative Agency, World Wildlife Fund, Environmental Defense Fund, Center for Research on Multinational Corporations (SOMO), Amazon Watch, Sierra Club and International Labor Organization. We skimmed press releases and executive summaries of NGO reports, followed by a full reading of the reports themselves.

\section{Scant attention to specific corporations (Heading level 1)}

Scopus yielded 10,830 publications related to supply chains. These crossed multiple disciplines and thought traditions. Supply chain management scholarship featured prominently $(3,427$ results), particularly value stream analysis (980 results). This is expected is given the work focuses on how to optimize information and material exchanges across a supply chain. Industrial ecology methods were also prevalent, with thousands of results for searches containing 'life cycle assessment' and 'supply chains' (1340 results) or 'companies' (1213 results), and case studies of industrial symbiosis (195 results). Another key collection of literature used theories and approaches from geography and sociology, namely, work in the area of global value chains (1306 studies), global commodity chains (261 studies) and global production networks (677 studies).

Despite this voluminous literature, we identified just 57 studies ( $0.5 \%)$ that fulfilled the four criteria (Tables 1 and 2). Thirty alone came from NGOs, with twenty-seven from academics, primarily the literature on global value chains (GCC), global commodity chains (GVC) and global production networks (GPN). GCC analyses focus on the historical reconstruction of 'chains' that produce consumables, including identifying geographic configuration and unequal divisions of labor and value in the various production processes (Hopkins and Wallerstein 1977). In essence, this 'world-systems' approach focuses on: (i) physical input-output structure of interlinked processes producing goods; (ii) territorial configurations of commodity chains; and (iii) buyer-driven vs. producer-driven governance modes (Gereffi 1994). GVC analyses expand on the inter-firm governance structures identified global commodity chain work, emphasizing in particular the institutional context and unequal value capture across the chain (Gereffi et 
al. 2005). GPN analyses prioritize the spatiality of production systems, particularly how they embed within different institutional and environmental contexts, and how these in turn influence firm behavior and inter-firm relations (Coe et al. 2008).

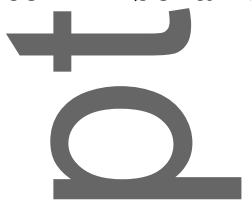

Table 1. Corporate actor tracking research in NGO literature.

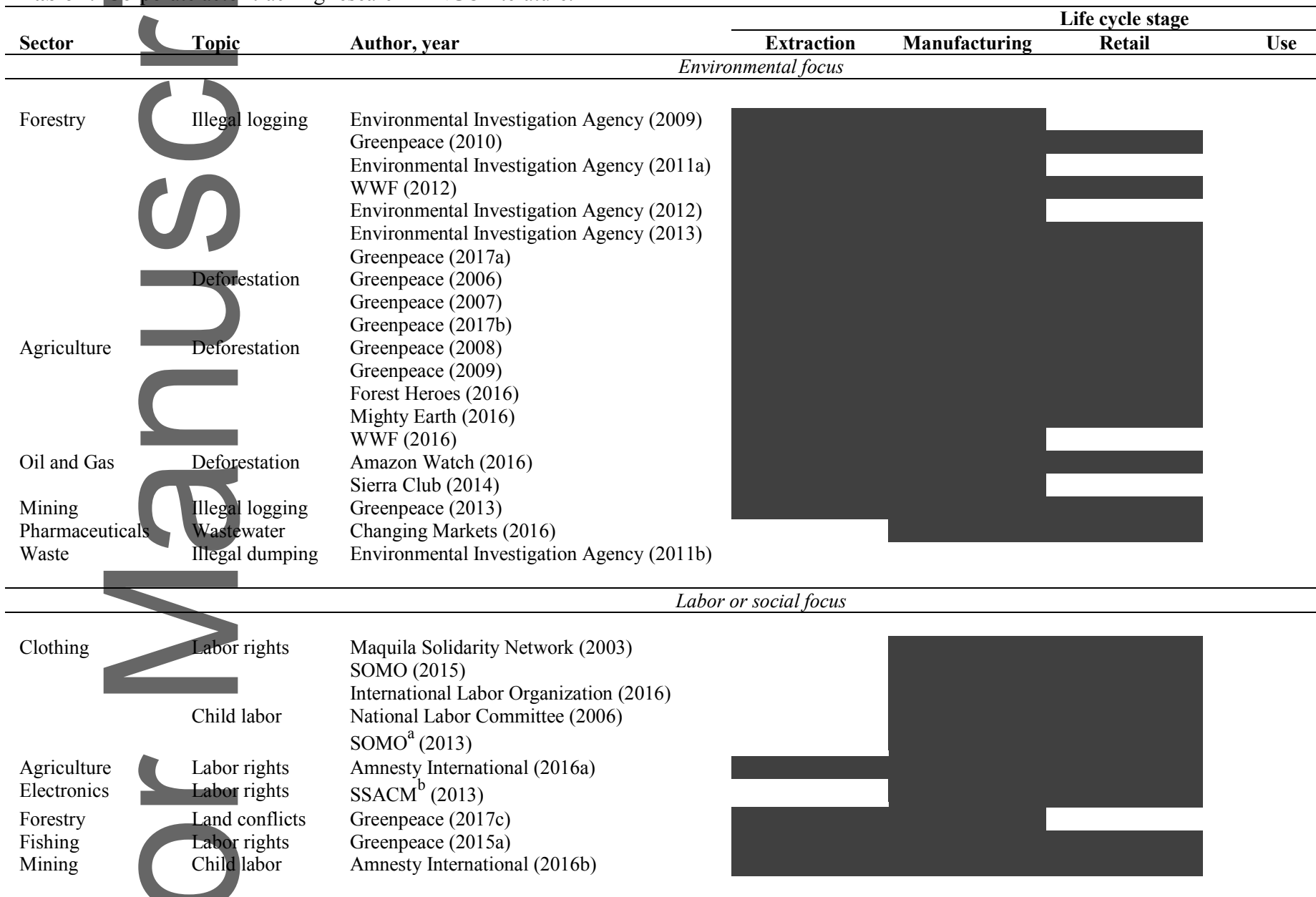

Note: Shaded cells represent the portions of the supply chain covered by the study.

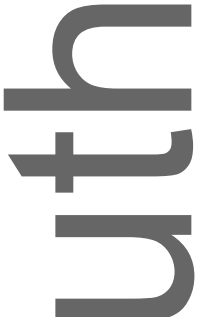

Table 2: Corporate actor tracking research in academic literature.

\begin{tabular}{|c|c|c|c|c|c|c|c|c|}
\hline \multirow{2}{*}{\multicolumn{2}{|c|}{ Sector }} & \multirow[t]{2}{*}{ Author, year } & \multirow{2}{*}{$\begin{array}{l}\text { GCC, GVC or } \\
\text { GPN }\end{array}$} & \multicolumn{5}{|c|}{ Life cycle stage } \\
\hline & & & & Extraction & Manufacturing & Retail & Use & $\begin{array}{c}\text { End-of- } \\
\text { life }\end{array}$ \\
\hline \multicolumn{9}{|c|}{ Supply chain governance or economic development focus } \\
\hline \multirow[t]{5}{*}{ Agriculture } & Governance & Fold (2002) & GCC & & & & & \\
\hline & & Fold et al. (2008) & GVC & & & & & \\
\hline & & Tipples (2008) & - & & & & & \\
\hline & & Wilson (1996) & - & & & & & \\
\hline & Upgrading & Ponte et al. (2009) & GVC & & & & & \\
\hline
\end{tabular}




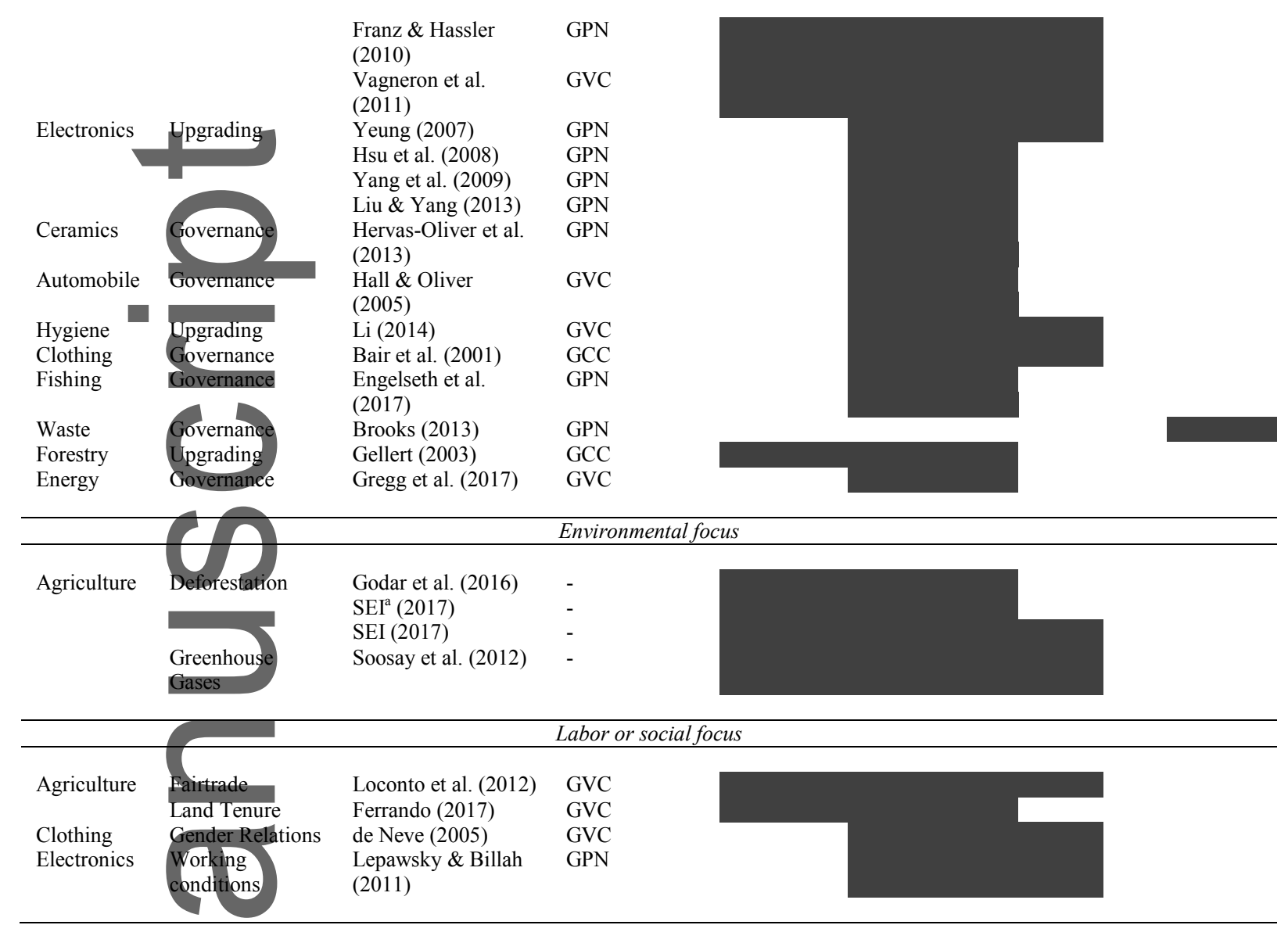

Note: Shaded cells represent the portions of the supply chain covered by the study.
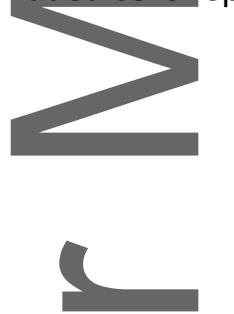

Of the 57 identified papers, 24 addressed environmental and resource issues, 19 addressed supply chain governance and economic development, and 14 studied labor and social issues. Agriculture (18 studies) and forestry (10 studies) dominated the environmental research; other represented sectors were mining, fishing, oil and gas, and waste. Studies that focused on labor and social issues included the clothing ( 7 studies) and electronics ( 6 studies) sectors. The 19 studies related to governance and economic development covered a wide variety of sectors, with agriculture and electronics prominently figured. Overlap in academic and NGO concerns existed for the environmental and social issues, but governance and economic development were solely areas of academic interest.

Tables 1 and 2 show the portion of the supply chain each study covered, according to the conventional life-cycle stages (resource extraction, manufacturing, use, and end-of-life) plus retail. Manufacturing received the most attention (55 studies), followed by retail (36 studies), and resource extraction (26 studies). End-of-life saw little attention ( 2 studies), and no studies included the use stage. Emerging ownership models, such as product-service systems, will necessitate inclusion of the use stage. NGOs displayed broad supply chain coverage (16 studies covering 3 stages), with comparable concern for extraction (22 studies), manufacturing (29 studies), and retail (23 studies). 
This stems from their goal of changing industry by linking brands and retailers to upstream issues in extractive zones and factories. Only 8 academic studies covered 3 stages and manufacturing received the most academic attention with 26 studies. The emphasis on manufacturing in the academic literature relates to governance and economic development studies, a focus of GCC, GVC and GPN scholars. These scholars focus especially on upgrading in the manufacturing stage(Bloomfield 2017). Just 5 of 19 governance and economic development studies considering extraction to retail; the remainder focused on manufacturing.

The geography of the supply chains also varied across the studies (Figure 1A-C and Tables S2S3 in the supporting information S1 on the Web). Studies of resource extraction focused ion resource-rich regions (equatorial regions and boreal forests), often areas with human rights or environmental issues, with Brazil and Indonesia as hotspots. Studies on manufacturing centered on the U.S. and China, and, to a lesser degree, Western Europe, India, and Brazil. There was a notable 'south-north' direction of the investigated supply chains, with the bulk of retailers in wealthy, western countries. The transition economies and their burgeoning consumer class were underrepresented as final markets, echoing Bloomfield's $(2017,2014)$ observations of GCC, GVC, and GPN scholarship and criticism of NGO campaigns.

\section{No identified studies in Industrial Ecology (Heading level 2)}

We found no industrial ecology studies that met our four criteria. The bulk of the research analyzed generic products or sectors to highlight how environmental and resource intensity differ between functional units, production methods, and consumption regimes. This work can help inform policy and-design 'greener' products but does not explicitly contribute to a political-industrial ecology of corporate supply chains. Industrial ecologists have assessed the environmental performance of corporations and brands, including Motorola (Rock et al. 2006), PepsiCo Inc. (Meinrenken et al. 2014), Mars Inc. (Ridoutt et al. 2009), Tyson (Smith et al. 2017), and Yale University (Thurston and Eckelman 2011). Many of these were industry collaborations (failed criterion 4) that avoided the critical perspectives we propose. It was also common to not identify upstream suppliers (failed criterion 2), though this did not stop some researchers from taking a more adversarial tact by ranking company environmental performance (e.g. Smith et al. 2017). Numerous studies analyzed industrial symbiosis between specific firms (e.g. Krones 2017), but these relied on previously published work (failed criterion 3 ) or industry collaboration.

Three suitable studies did relate loosely to industrial ecology. Two of them, one by Godar et al. (2016) and a related one by the Stockholm Environmental Institute (2017), were a criticism of process-based LCA, especially its perceived vague policy implications and onerous data demands . The third paper used carbon footprint to complement an analysis of the management of wine supply chains (Soosay et al. 2012).

\footnotetext{
Of the thousands of industrial ecology studies in Scopus, only a few analyzed particular corporations, often in ways that avoided tough questions about their supply chains and business practices. Why industrial ecologists have focused so little on specific corporations is unclear. Much like NGOs, industrial ecologists view companies as fulcrums of environmental and social change (Lifset and Graedel 2002; Dauvergne and Lebaron 2014). Both promote market mechanisms to move producers and consumers towards sustainability (Bloomfield 2014). O'Rourke et al. (1996) suggests the reason lies with a predominant belief in the ability of technology address resource scarcity and
} 
global environmental collapse. Industry is the favored vehicle to reduce its environmental impacts (Boons and Roome 2000) and there is preference for 'light' regulation, using taxation to incentivize corporate environmentalism (O'Rourke et al. 1996; Deutz 2009). Moreover, early industrial ecologists suggested avoiding normative opinions, sticking to the science and eschewing activism (Boons and Roome 2000).

\section{Corporate Actor Tracking Methods: Ex-Situ, In-Situ and Hybrid (Heading level 2)}

In the 57 studies we identified, researchers used two distinct approaches; ex-situ and in-situ. Ex-situ approaches use secondary data sourced from customs datasets, annual stockholder reports, corporate sustainability reports, company websites, media reports and confidential internal memos. In-situ approaches generate primary data through interviews, site visits, surveys, surveillance, and other fieldwork.

One ex-situ approach entailed reading documents to identify suppliers, corporate subsidiaries, and customers. Internal company reports enabled Greenpeace to track illegal timber flows from forests to Chinese paper mills (2010). Amnesty International (2016a; 2016b) used investor documents to connect African exporters of cobalt to Chinese electronics firms and used corporate websites to link palm-oil refinery operators with parent companies. Hsu et al. (2008) mined media reports and other sources to build linkages between electronic component producers to global brand-name manufacturers. This document review is labor intensive, which can limit its scalability when applied to complex supply chains that may include dozens of firms.

Researchers also identify supply chains using semi-structured and structured data. These data have standard forms, syntaxes, and characteristics that facilitate and expedite their combination, manipulation, and retrieval, particularly using computer automation. Commonly used datasets include customs data of cross-border shipments ('bill-of-lading' data), geospatial data, national input-output tables, and agricultural production statistics. A good example of this is the Godar et al. (2016) study, which linked Indonesian palm oil to global commodity markets. Using bilateral customs datasets of waterborne palm oil trade, they identified Indonesian exporters and foreign importers alongside their respective trade volumes for thousands of palm oil shipments. They then combined district-level production data, transport network data and port locations to build a minimum transport cost model that linked palm from municipalities to likely locations of export or storage. Global bilateral trade data from United Nations FAOSTAT of national-level agricultural commodity exchange supported a quasi-input-output model capturing transshipments from countries that imported and then re-exported Indonesian palm oil.

In-situ research typically entails interacting directly with supply chain actors through interviews, surveys, and site visits. Time and labor-intensive, this research focuses on one or a few actors or study sites. Multiple academic studies have relied on interviews to link suppliers and customers (see Bair and Gereffi, 2001; Fold and Gough, 2008; Gellert, 2003) and surveys (Vagneron and Roquigny 2011). NGOs have interviewed garment factory and agricultural workers to document labor infractions (Amnesty International 2016; National Labor Committee 2006; Greenpeace 2015). Site visits can also include direct observations. The brands produced at factories can be determined by visual inspection (Environmental Investigation Agency 2013) or packaging labels can reveal the origin of an item sold at a market (Brooks 2013). During site visits, researchers will also document 
local impacts, such as deforestation in Brazil (Mighty Earth 2016) or Madagascar (Global Witness and Environmental Investigation Agency 2009).

In-situ research can also involve the use of surveillance, in which researchers clandestinely observe and document activities along the supply chain. The Environmental Investigation Agency (EIA) is one NGO that has pioneered surveillance methods, often going undercover by posing as buyers. To document the use of illegal Laotian timber in Vietnamese furniture factories, they surreptitiously recorded conversations with factory managers (Environmental Investigation Agency 2011a). Surveillance can also include in-person or remotely tracking a supply chain, often without prior consent. McDowell et al. (2015) followed trucks from ports to factories to link U.S. consumers of tuna to thai fishing vessels suspected of human trafficking. Similarly, WWF (2016b) followed trucks carrying palm-fruit from Indonesian national parks to mills. To follow illegal waste dumping in Nigeria, EIA (2011b) investigators planted GPS tracking devices inside defective computer monitors. Although in-situ methods often provide key details when ex-situ data are lacking or companies are unwilling to cooperate with investigators, gathering information under false pretenses, failing to anonymize interviewees, and surveilling firms all contravene academic codes of conduct.

Academics and NGOs use both in-situ and ex-situ approaches (Figure 2A-C and Tables S4-S5 in the supporting information on the Web). However, NGOs tended to rely more on ex-situ, whereas academics used more of a blend. Interviews were especially prominent in the academic studies. Particular ex-situ or in-situ methods were not associated with specific supply chain stages, with one exception: Land parcel maps were often useful in identifying firms involved in raw material extraction. Of the 57 studies, 13 used a hybrid approach, combining in-situ and ex-situ methods (Figure 3).For example, to illustrate how the Burger King supply chain is connected to rainforest degradation, NGO Mighty Earth (2016), used customs data and models (ex-situ) to identify exact Amazonian rainforest tracts likely cleared for soy plantations. Researchers then used aerial drones to document rainforest clearing at these sites (in-situ). Hybrid studies illuminate the complementary strengths of ex-situ and in-situ approaches. Ex-situ approaches can make large numbers of inter-firm linkages, sketch the territoriality of a supply chain, and identify potentially problematic companies using remote-sensing data. In-situ approaches can perform in-depth analysis of particular companies, capture 'leakage' of illicit goods into supply chains, and document environmental and social change at specific sites.

\section{Why and how should academics study specific corporations and their supply chains (Heading Level 1)}

We have provided multiple reasons for why academics should study the supply chains of specific corporations. First, we have noted their enormous size and geographic reach, some are larger than the GDP of entire countries. Second, as NGOs have demonstrated, focusing on specific corporate brands can lead to significant improvements in terms of supply chain transparency and sustainable sourcing. Third, academics enjoy high levels of public trust and have the methodological toolkit that can build off these approaches to systematically link corporate actors together across the supply chain and evaluate the environmental and social impacts.

Although our review found a burgeoning collection of research on corporate supply chains, the work remains to be done. Just fifty-seven papers out of $\sim 11,000$ identified studies focused on the corporate scale. This nascent work on corporate supply chains encompasses three research 
streams: 1) 'brand activism' campaigns by NGOs to compel companies and sectors to produce more sustainably; 2 ) social scientists who formulate, validate and refine theories on global commodity chains (GCC), global value chains (GVC) and global production networks (GPN); and 3) other academics who analyze the environmental impacts of global commodity trade, focusing on precise locations of resource extraction and the companies importing and exporting these commodities. This research uses ex-situ and in-situ approaches to map out the supply chain structures of specific corporations. Conspicuously, we found no relevant studies by industrial ecologists.

In the remainder of this paper, we summarize a methodology to systematically track these corporate supply chains across space and time, noting data challenges and societal linkages. This involves combining LCA procedures with in-situ and ex-situ data gathering techniques. Then, we conclude by calling for a broader political-industrial ecology of corporate supply chains and brands. This combines the methodological toolkit of industrial ecology with the theoretical and methodological expertise found in the social sciences, especially the work by sociologists, geographers, and political economists. To indicate how this can occur, we briefly illustrate how LCA and in-situ and ex-situ data gathering can be used track corporate actors across space and time.

\section{Tracking corporate actors and fostering sustainability (Heading Level 2)}

In a related paper (Goldstein and Newell (2019), we provide a detailed methodology - Tracking Corporate Actors Across Space and Time (TRACAST) - for how to map out the supply chains of specific corporations. This method has four steps: (i) scope study, (ii) collect data, (iii) identify and verify corporate actor linkages, and (iv) evaluate environmental and socio-economic impacts. Here we briefly-summarize the TRACAST method.

Akin to an LCA, a researcher scopes the study by specifying a product of interest, by sketching a 'product-system diagram' of supply chain steps, and by delineating the study's geographic and temporal focus. After scoping, the researcher collects data. Bill-of-lading data, such as IHS Markit PIERS (https://ihsmarkit.com/products/piers.html), document international trade between companies. Financial analysis tools, such as Bloomberg Terminal (www.bloomberg.com), do this domestically. Table $\mathrm{S} 6$ in the supporting information on the Web lists potentially useful free and commercial datasets. With ex-situ data, researchers can start the third step of building linkages between companies, often by finding companies common across datasets that link multiple supply chain steps. In-situ data can capture more supply chain steps and confirm linkages.

Step four links specific corporate actors to environmental and social change. To avoid simply conveying a company's share of average market impacts, researchers need companyspecific data. Fortunately, company location is often revealed alongside identity. Researchers can use this information to develop spatially-explicit LCAs linking companies to hotspots of environmental impacts. Remote sensing data and tools from land change science can aid here. For the social dimensions, ex-situ data can identify companies for social-LCA analysis without requiring industry collaboration (which might limit the release of unfavorable findings). Scorecards of labor conditions at specific factories, such as the 'Better Work' project (www.betterwork.org), can also inform social-LCA. Lastly, as we expand on below, analysis using political-industrial ecology explores issues of justice, equity and power along the supply chain. 


\section{Data Challenges (Heading Level 2)}

Although some companies make their supply chains transparent (see Table S6 in the supporting information on the Web for example initiatives), others consider it a proprietary source of competitive advantage (Doorey 2011; Kashmanian 2017; O'Rourke 2014). So, public data can be limited for some supply chains. Available data may contain numerous complications. For instance, the following might afflict customs data alone: company names anonymized, only one company in a transaction listed, data recorded in a foreign language, or no data on mass traded between companies. Some gaps can be easily overcome (e.g. language translation), while others cannot (e.g. company anonymization). Company-level data are usually produced when governments collect tariffs on imported goods or monitor exports. Because tariffs are not paid on domestic shipments, transaction-level data on trade within countries are scarce. In-situ methods can fill these gaps. Researchers may also need to visit sites along the supply chain to capture undocumented or improperly documented flows of goods into the supply chain ('leakage') and to confirm whether goods from different sources are blended together at certain nodes in the supply chain (Newell 2008).

\section{Societal Impact of Research (Heading Level 2)}

Peer-reviewed publications that use robust scientific methods and avoid misrepresentations of transparency data (Gardner et al. 2018) would be of significant interest to media, NGOs, and corporate actors, especially given the high level of trust enjoyed by academics. Media coverage and NGO campaigns can produce improvements in corporate supply chains or alert regulatory ageneies with remit to punish environmental crimes (Gibson and Warren 2016). Both NGOs and academics have collaborated with industry to audit and improve certification schemes (Gibbs et al. 2016; Dauvergne 2017). Academics can create websites, such as TRASE (www.trase.earth), that enable the public to visualize the impacts from corporate supply chains. NGOs have utilized such publicly available data to support their work. For example, Mighty Earth (2016b) used the Stockholm Environment Institute's TRASE database to support their Burger King campaign. Under the right circumstances, direct collaboration between NGOs and academics could be mutually beneficial.

\section{A political-industrial ecology of corporate supply chains (Heading Level 2)}

Political-industrial ecology uses mixed methods to understand how environmental, socioeconomic, and political processes shape the stocks and flows of material and energy across space and time (Newell et al. 2017). It combines the quantitative tools of industrial ecology with theories and methods from the social sciences, namely political ecology but not exclusively. By addressing the sociopolitical dimensions often given short shrift in industrial ecology, political-industrial ecology provides a more nuanced understanding of sustainability across production-consumption nexus. Political-industrial ecology is committed to using this knowledge to re-shape nature-society relations around principles of equity and justice (Newell and Cousins 2014).

With respect to developing a political-industrial ecology of supply chains and brands, we can identify three developments. First, this work would publish rigorous methodological studies on the supply chains of specific companies, using TRACAST and related approaches. It would nudge corporations to build more sustainable and fairer supply chains. Second, this work would identify 
hotspots of impact in supply chains and the processes that lead to their creation. In this vein, work by political ecologists and scholars of GCC, GVC, and GPN have much to contribute. Political ecology 'chains of explanation', for example, explain causal (often distant) political-economic mechanisms behind localimpacts in specific places (Robbins 2012). Work on global production networks (GPNs) similarly links global pressures to local changes, and provides the concept of 'embeddedness' to explain why some supply chains are fixed in space (while others are more fluid); thus, how they become embedded as social systems and networks of corporate actors and places (Hess 2004). Third, studying corporate supply chains grapples with the unequal distribution of benefits and costs, as part of a commitment to justice and equity. Work in urban political-ecology on 'urban metabolism' explain why supply chains (re)produce hotspots of impacts and create environmental, social, and economic 'winners and losers.' (Heynen et al. 2006) Likewise, GCC and GVC analyses explore power asymmetries in supply chains and unequal value capture (Gereffi et al. 1994).

Like industrial ecologists, GCC, GVC, and GPN scholars study supply chains. They focus on the social and spatial dimensions of industrial organization, while industrial ecologists prioritize environmental aspects. A political-industrial ecology framework would simultaneously address environmental, social and spatial aspects of production and consumption, rather than a focus primarily on just one (Newell et al. 2017). This interdisciplinary work would strengthen industrial ecology while reciprocally addressing gaps in GCC, GVC and GPN work: only limited attention to environmental impacts (Bolwig et al. 2010) and a focus on extractive sites and factories (Bloomfield 2017). Given that consumers seek brands aligned with their personal values (Rindell et al. 2014), this work could be of interest outside the academy. Working alongside NGOs or building public-facing web-tools can amplify this message and nudge corporations or sectors towards sustainability. In a time of escalating environmental degradation (Steffen and et at 2018) and labor exploitation (International Labor Organization 2017a, 2017b), academics need to explore all avenues in working towards this elusive goal. Ultimately, linking specific brands to environmental and social impacts is an important way for academics to use their trusted voices to catalyze an urgently needed shift towards an economy that respects people and planet.

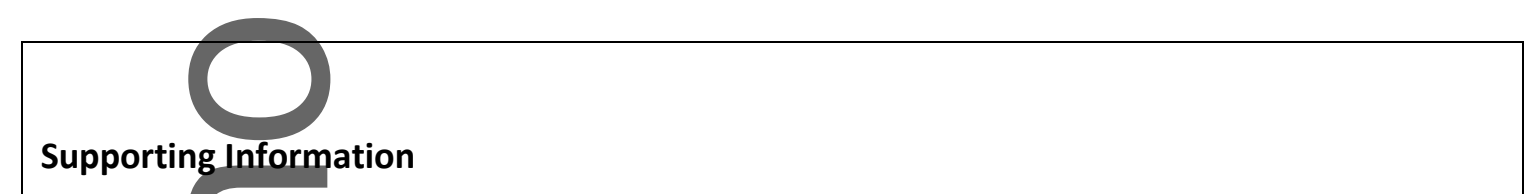

Additional supporting information may be found in the online version of this article:

Supporting Information S1: This supporting information provides: (i) a table of the search terms we used and Scopus results; (ii) a summary of corporate actor tracking work by NGOs and academics, including locations of supply chain activities; (iii) the types of tactics used in the NGO and academic literature, respectively; and (iv) a sampling of relevant data sources for this work.

Supporting Information S2: This supporting information provides the numeric data used in Figures 1, 2 and 3. 


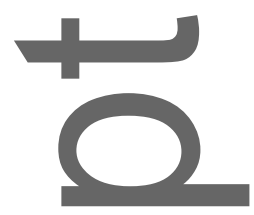

Figure Captions

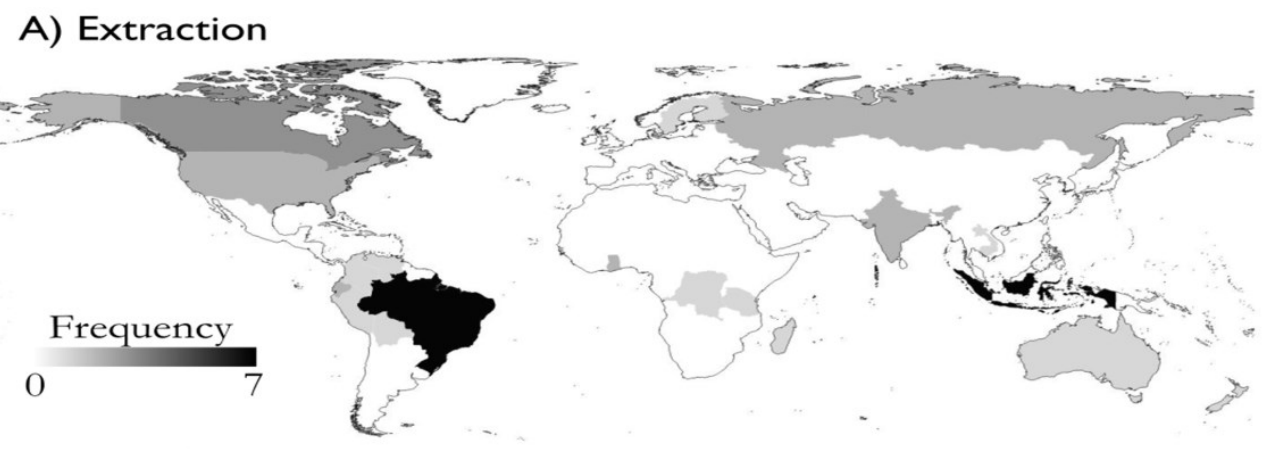

B) Manufacturing
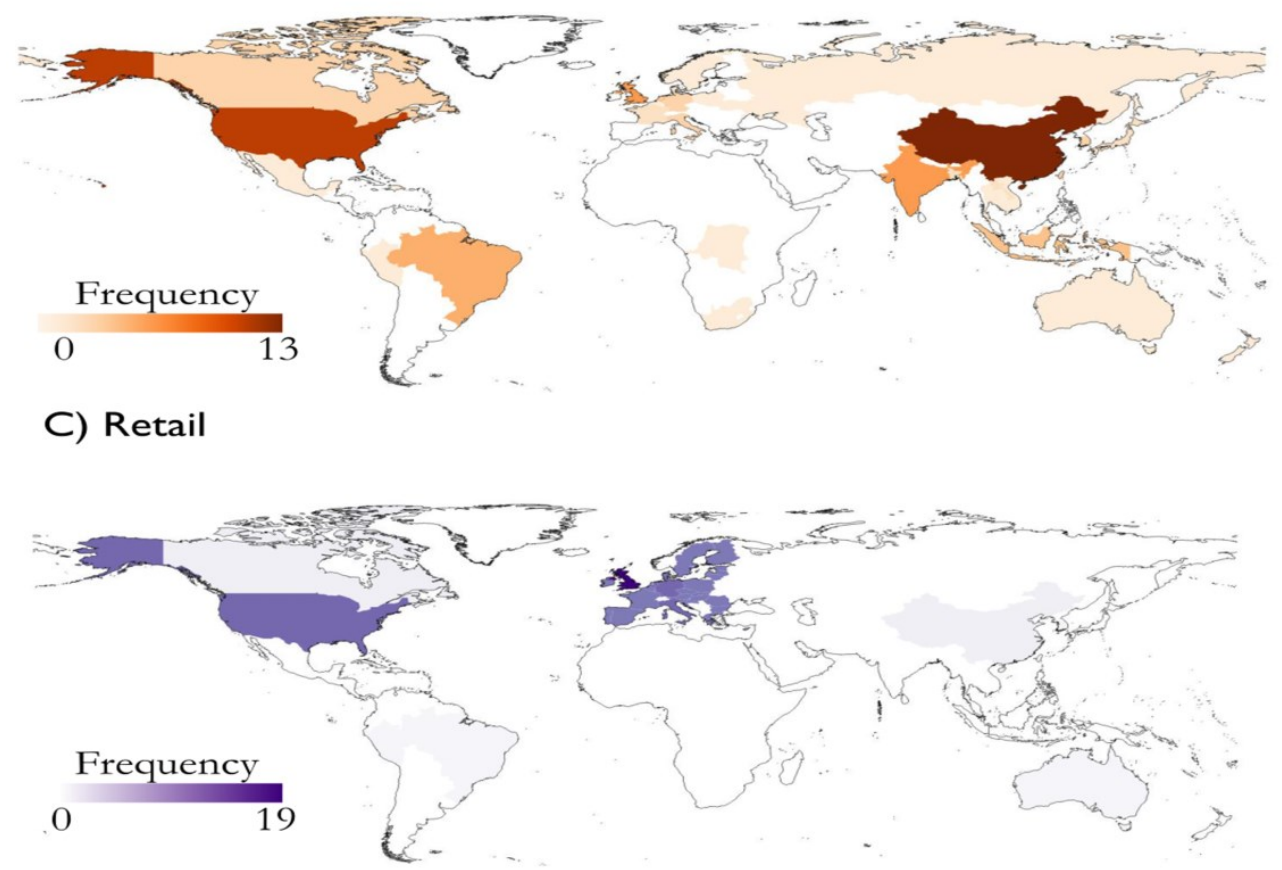

Figure 1: Geographic distribution of (A) extraction, (B) manufacturing, and (C) retail corporate actors in the literature based on frequency of occurrence. End-of-life not shown here due to limited coverage in reviewed literature, but is available in Table $\mathrm{S} 1$ in the supporting information on the Web. Underlying data used to create this figure can be found in the supporting information S2. 

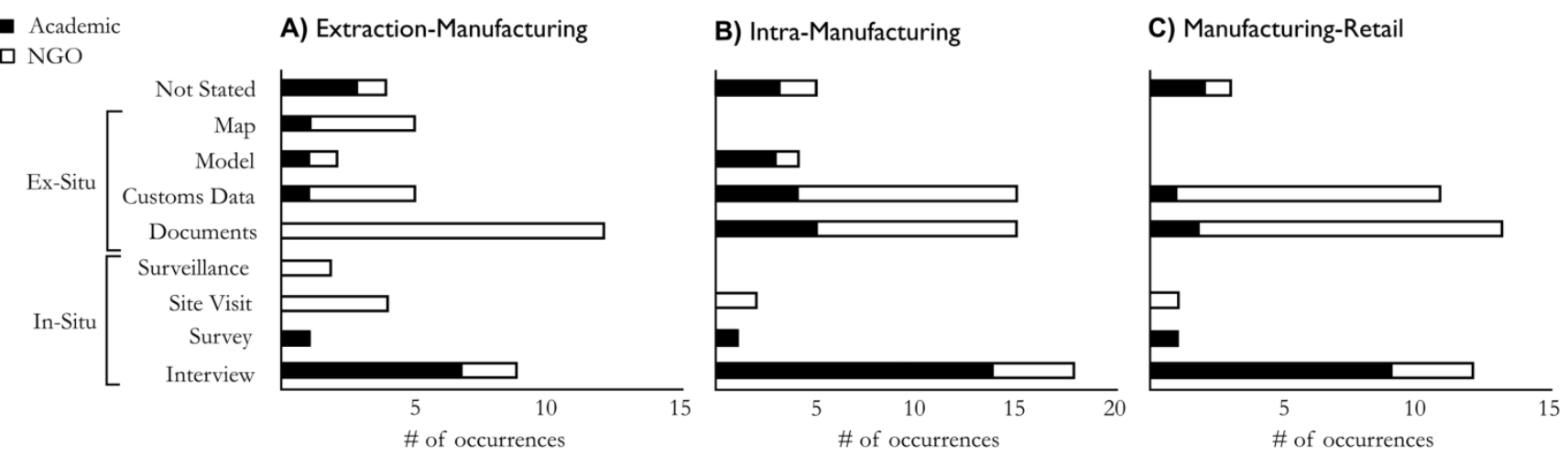

Figure 2: Application of different data sources to make (A) extraction-manufacturing, (B) intra-manufacturing, and (C) manufacturing-retail corporate actor linkages in the reviewed literature. Underlying data used to create this figure can be found in the supporting information $\mathrm{S} 2$.

\section{Study type}

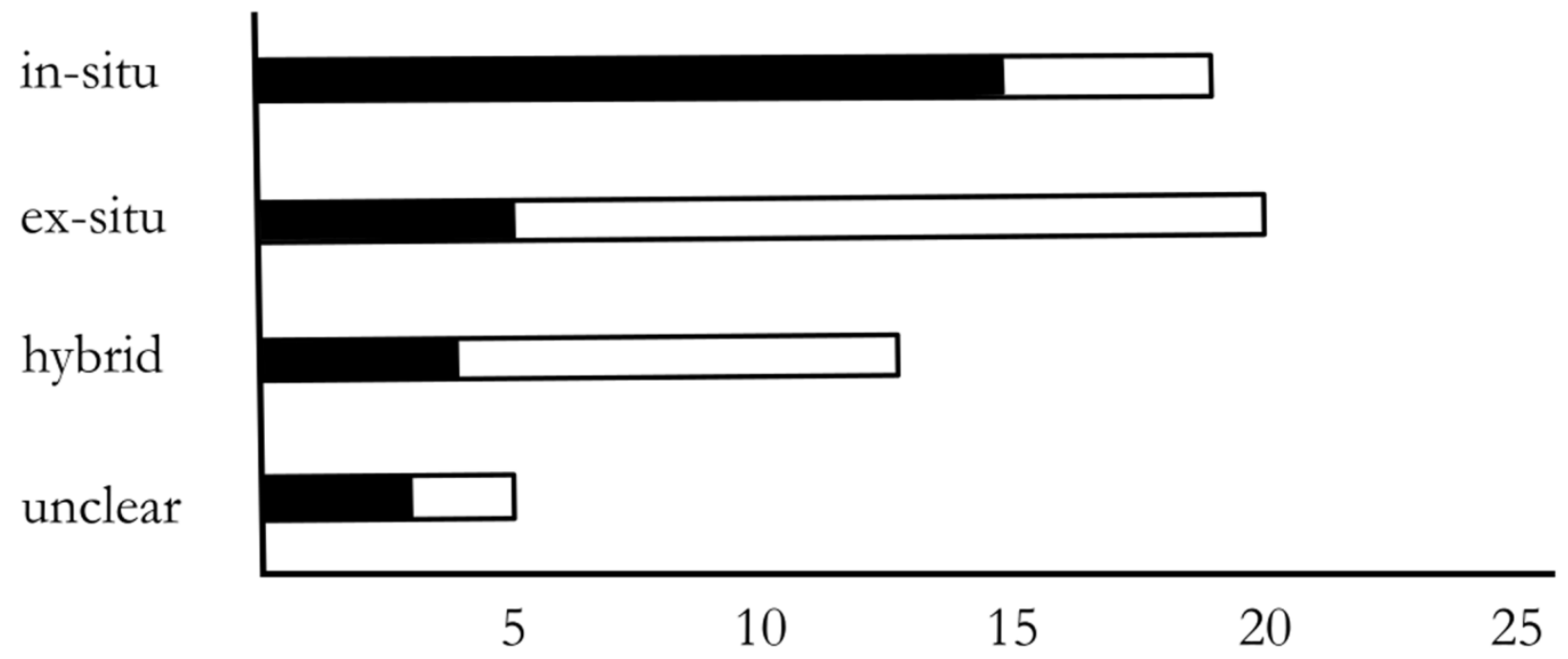

- Academic

\# of studies

$\square$ NGO

Figure 3: Each study based on the methods applied, where hybrid describes a mix of in- and ex-situ methods. Underlying data used to create this figure can be found in the supporting information $\mathrm{S} 2$.

\section{References (Heading Level 1)}

Amnesty International. 2016. The great palm oil scandal.

Bair, J. and G. Gereffi. 2001. Local clusters in global chains: The causes and consequences of export dynamism in Torreon's Blue Jeans industry. World Development 29(11): 18851903.

Bartley, T. 2018. Transnational standards and empty spaces. In Rules Without Rights, 1-36. Oxford, UK: Oxford University Press. 
Bloomfield, M.J. 2014. Shame campaigns and environmental justice: corporate shaming as activist strategy. Environmental Politics 23(2): 263-281.

Bloomfield, M.J. 2017. Global Production Networks and Activism: Can Activists Change Mining Practices by Targeting Brands? New Political Economy 22(6): 727-742.

Bolwig, S., S. Ponte, A. du Toit Riisgaard, Lone, and N. Halberg. 2010. Integrating poverty and environmental concerns in to value chain analysis. A conceptual framework. Devetopment Policy Review 28 (2) 28(2): 173-194.

Boons, F. and N. Roome. 2000. Industrial Ecology as a Cultural Phenomenon: On Objectivity as a Normative Position. Journal of Industrial Ecology 4(2): 49-54.

Brooks, A. 2013. Stretching global production networks: The international second-hand clothing trade. Geoforum 44: 10-22.

Center for Research on Multinational Corporations. 2016. Flawed fabrics.

Chrun, E., N. Dolsak, and A. Prakash. 2016. Corporate Environmentalism: Motivations and Mechanisms. Annual Review of Environment and Resources 41: 341-362.

Coe, N.M., P.Dicken, and M. Hess. 2008. Global production networks: realizing the potential. Journal of Economic Geography 8: 271-295.

Dauvergne, P. 2017. Is the Power of Brand-Focused Activism Rising? The Case of Tropical Deforestation. Journal of Environment \& Development 26(2): 135-155.

Dauvergne, P. and G. Lebaron. 2014. Protest Inc. Cambridge, UK: Polity Press.

Deutz, P. 2009. Producer responsibility in a sustainable development context: Ecological modernisation or industrial ecology? Geographical Journal 175(4): 274-285.

Dicken, P. 2011. Global Shift: Mapping the Changing Contours of the World Economy. The Guildford Press. Vol. 6th.

Doorey, D.J. 2011. The Transparent Supply Chain: from Resistance to Implementation at Nike and Levi-Strauss. Journal of Business Ethics 103(4): 587-603.

Edelman. 2017.2017 Edelman Trust Barometer. https://www.edelman.com/research/2017trust-barometer-global-results. Accessed August 27, 2018.

Environmental Investigation Agency. 2011a. Crossroads - The Illicit Timber Trade Between Laos and Vietnam.

Environmental Investigation Agency. 2011b. System Failure - The UK's harmful trade in electronic waste.

Environmental Investigation Agency. 2013. Liquidating the Forests.

Fold, N. and K.V. Gough. 2008. From smallholders to transnationals: The impact of changing consumer preferences in the EU on Ghana's pineapple sector. Geoforum 39(5): 1687-1697.

Gardner, T.A., M. Benzie, J. Börner, E. Dawkins, S. Fick, R. Garrett, J. Godar, et al. 2018. Transparency and sustainability in global commodity supply chains. World Devetopment.

Gellert, P.2003. Renegotiating a Timber Commodity Chain : Lessons from Indonesia on the Political Construction of Global Commodity Chains 18(1): 53-84.

Gereffi, G. 1994. The organization of buyer-driven global commodity chains: How U.S. retailers shape overseas production networks. Commodity Chains and Global Capitalism(January 1994): 95-122.

Gereffi, G., R. Garcia-Johnson, and E. Sasser. 2001. The NGO-Industrial Complex. Foreign Policy(125): 56.

Gereffi, G., J. Humphrey, R. Kaplinsky, and T. Sturgeon. 1994. Globailisation, Value Chains and Development. IDS Bulletin 32(3): 1-8.

Gereffi, G., J. Humphrey, and T. Sturgeon. 2005. The governance of global value chains. 
Review of International Political Economy 12(1): 78-104.

Gibbs, H.K., J. Munger, J. L’Roe, P. Barreto, R. Pereira, M. Christie, T. Amaral, and N.F. Walker. 2016. Did Ranchers and Slaughterhouses Respond to Zero-Deforestation Agreements in the Brazilian Amazon? Conservation Letters 9(1): 32-42.

Gibson, C. and A. Warren. 2016. Resource-Sensitive Global Production Networks: Reconfigured Geographies of Timber and Acoustic Guitar Manufacturing. Economic Geography 92(4): 430-454.

Global Justice Now. 2016. 10 biggest corporations make more money than most countries in the world. http://www.globaljustice.org.uk/news/2016/sep/12/10-biggestcorporations-make-more-money-most-countries-world-combined. Accessed August 9, 2018

Global Witness and Environmental Investigation Agency. 2009. Investigation into the illegal felling, transport and export of precious wood in SAVA region Madagascar.

Godar, J., C. Suayet, T.A. Gardner, E. Dawkins, and P. Meyfroidt. 2016. Balancing detail and scale in assessing transparency to improve the governance of agricultural commodity supply chains. Environmental Research Letters 11(3): 35015.

GRAIN and IATP. 2018. Emissions impossible - How big meat and dairy are heating up the planet.

Greenpeace. 2010. How Sinar Mas is pulping the planet.

Greenpeace. 2015. Supply Chained - Human rights abuses in global tuna chain.

Griffin, P. 2017. The Carbon Majors Database CDP: Carbon Majors Report 2017.

Hess, M. 2004. 'Spatial' relationships? Towards a reconceptualization of embedded ness. Progress in Human Geography 28(2): 165-186.

Heynen, N., M. Kaika, and E. Swyngedouw. 2006. Urban political ecology politicizing the production of urban natures. In In the Nature of Cities: Urban Political Ecology and the Politics of Urban Metabolism, ed. by Nik Heynen, Maria Kaika, and Erik Swyngedouw, 1-20. London and New York: Routledge.

Hopkins, T.K. and I. Wallerstein. 1977. Patterns of development of the modern worldsystem. Review 1(2): 111-145.

Houpt, S. 2011. Beyond the bottle: Coke trumpets its green initiatives. The Globe and Mail, January 13.

Interbrand. 2018. Activating Brave: Best Global Brands 2018.

International Labor Organization. 2017a. Global Estimates of Child Labour: Results and trends, 2012-2016.

International Labor Organization. 2017b. Global Estimates of Modern Slavery - Forced Labour and Forced Marriage.

Kashmanian, R.M. 2017. Building Greater Transparency in Supply Chains to Advance Sustainability. Environmental Quality Management 26(3): 73-104.

Klooster, D. 2005. Environmental certification of forests: The evolution of environmental governance in a commodity network. Journal of Rural Studies 21: 403-417.

Klooster, D. 2006. Environmental certification of forests in Mexico: The political ecology of a nongovernmental market intervention. Annals of the Association of American Geographers 96(3): 541-546.

Krones, J.S. 2017. Industrial symbiosis in the Upper Valley: A study of the CasellaHypertherm Recycling Partnership. Sustainability (Switzerland) 9(5).

Lebaron, G. and J. Lister. 2015. Benchmarking global supply chains: The power of the "ethical audit" regime. Review of International Studies 41(5): 905-924.

Lifset, R. and T.E. Graedel. 2002. Industrial ecology: goals and definitions. In A Handbook 
of Industrial Ecology, ed. by Robert Ayres and L Ayres, 3-15. Edward Elgar.

McDowell, R., M. Mason, and M. Mendoza. 2015. Slaves may have caught the fish you bought. Associated Press.

Meinrenken, C.J. B.C. Sauerhaft, A.N. Garvan, and K.S. Lackner. 2014. Combining life cycle assessment with data science to inform portfolio-level value-chain engineering: A Case Study at PepsiCo Inc. Journal of Industrial Ecology 18(5): 641-651.

Mighty Earth. 2016. The ultimate mystery meat.

National Labor Committee. 2006. Child labor is back.

Newell, J. 2008. Resource consumption as driver of environmental change : studies in foreign direet investment in Eastern Russia, urban water infrastucture in US cities, and global buyer-driven furniture chains. University of Washington.

Newell, J., J. Cousins, and J. Baka. 2017. Political-industrial ecology: An introduction. Geoforum 85: 319-323.

Newell, J.P. and J.J. Cousins. 2014. The boundaries of urban metabolism: Towards a political-industrial ecology. Progress in Human Geography 39(6).

O’Rourke,D. 2005. Market Movements: Nongovernmental Organization Strategies to Influence Global Production and Consumption. Journal of Industrial Ecology 9(1-2): $115-128$.

O'Rourke, D. 2014. The science of sustainable supply chains. Science 344(6188).

O’Rourke, D., L. Connelly, C.P. Koshland, D. Orourke, L. Connelly, and C.P. Koshland. 1996. Industrial Ecology: a Critical Review. Int. J. Environment and Pollution 6(2-3): 89112.

Ridoutt, B.G., S.J. Eady, J. Sellahewa, L. Simons, and R. Bektash. 2009. Water footprinting at the product brand level: case study and future challenges. Journal of Cleaner Production 17(13): 1228-1235.

Rindell, A., T. Strandvik, and K. Wilén. 2014. Ethical consumers' brand avoidance. Journal of Product and Brand Management 22(7): 484-490.

Robbins, P. 2012. A political ecology emerges. In Political Ecology: A Critical Introduction, 82-100. 2nd ed. Chichester, UK: John Wiley \& Sons Ltd.

Rock, M.T.,D.P. Angel, and L.L. Pao. 2006. Impact of firm-based environmental standards on subsidiaries and their suppliers: Evidence from Motorola-Penang. Journal of Industrial Ecology 10(1-2): 257-278.

Schanberg, S. 1996. Six Cents an Hour. Life Magazine, June.

Smith, T.M., A.L. Goodkind, T. Kim, R.E.O. Pelton, K. Suh, and J. Schmitt. 2017. Subnational mobility and consumption-based environmental accounting of US corn in animal protein and ethanol supply chains. Proceedings of the National Academy of Sciences of the United States of America: 2017-3793.

Soosay, C.A., A.P. Fearne, and B. Dent. 2012. Sustainable value chain analysis - a case study of Oxford Landing from "vine to dine." Supply Chain Management 17(1): 68-77.

Spar, D. and L. La Mure. 2003. The Power of Acvtivism:Assessing the Impasct of NGOs on GLobal Business. California Management Review 45(3): 78-104.

Steffen, W. and et al. 2018. Trajectories of the Earth System in the Anthropocene. Proceedings of the National Academy of Sciences of the United States of America in review: $1-45$.

Stockholm Environment Institute. 2017. TRASE. https://trase.earth/. Accessed December 7, 2017.

The World Bank. 2019. Agriculture, forestry, and fishing, value added (current US\$).

https://data.worldbank.org/indicator/NV.AGR.TOTL.CD. Accessed February 19, 2019. 
Thurston, M. and M.J. Eckelman. 2011. Assessing greenhouse gas emissions from university purchases. International Journal of Sustainability in Higher Education 12(3): 225235 .

Vagneron, I. and S. Roquigny. 2011. Value distribution in conventional, organic and fair trade banana chains in the Dominican Republic. Canadian Journal of Development Studies/Revue Canadienne d'études Du Développement 32(3): 324-338.

WWF. 2016a. No one is safe.

WWF. 2016b. No one is safe.


year (The World Bank 2019)

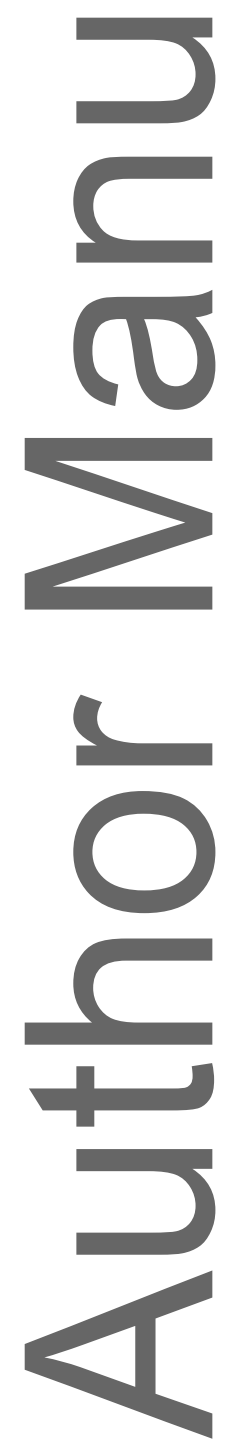

